\title{
Influence of overplanting paddy rice on irrigation water delivery performance: a case study in the Dakalt branch canal, Nile Delta of Egypt
}

\author{
Mohamed Farig ${ }^{1,2} \cdot$ Katsuyuki Shimizu $^{3}$ (D) Gamal El-Kassar $^{1} \cdot$ Waleed H. Abou El Hassan ${ }^{1,4} \cdot$ Haruyuki Fujimaki $^{5}$. \\ Ichiro Kita ${ }^{6} \cdot$ Tsugihiro Watanabe $^{7}$
}

Received: 22 January 2021 / Revised: 27 July 2021 / Accepted: 5 September 2021 / Published online: 12 October 2021

(c) The Author(s) 2021

\begin{abstract}
In the North Nile Delta of Egypt, the impacts of overplanting paddy rice on water delivery performance have not been discussed quantitatively. Further, the amount of water that could have been saved if farmers would follow the planned area is unknown. In this study, water delivery performance was assessed by comparison of actual paddy rice planting and the government's planned conditions. For both conditions, performance indicators relating to adequacy, equity, and dependability were analyzed across six locations in conjunction with the branch canal water level in 2013 and 2014. Based on the difference between the actual water supply and planned water demand, the amount of water that could have been saved for downstream uses was calculated. The average adequacy for the investigation period was good at one location, fair at 2 locations, and poor at 3 locations in both years. Further, adequacy under both actual and planned conditions was poor in late July at all locations. The planned adequacy and dependability downstream and equity among locations improved compared to the actual condition in both years. Under the condition that paddy rice area is the upper limit planned by the government, about $12.3 \%$ and $9.6 \%$ of water could be potentially saved in each year. The difference between actual and planned water delivery performance is caused by the branch canal's low water level. Control of overplanting paddy rice and coordination of water distribution among water user associations would improve stable water level in the canal and, eventually, water delivery performance.
\end{abstract}

Keywords Irrigation performance $\cdot$ Irrigation improvement project · Adequacy $\cdot$ Equity $\cdot$ Dependability $\cdot$ Dryland

Katsuyuki Shimizu

shimizu@tottori-u.ac.jp

1 National Water Research Center, Water Management Research Institute, NWRC Building, Delta Barrage 13621/5, Egypt

2 United Graduate School of Agriculture Science, Tottori University, 4-101 Koyamacho-Minami, Tottori, Japan

3 Faculty of Agriculture, Tottori University, 4-101 Koyamacho-Minami, Tottori, Japan

4 Food and Agriculture Organization (FAO), United Nations-Egypt, 11 Al Eslah El Zerai St, P.O. Box: 100, Dokki-CairoDokki, Egypt

5 Arid Land Research Center, Tottori University, 1390 Hamasaka, Tottori, Japan

6 Faculty of Life and Environmental Sciences, Shimane University, 1060 Nishikawatsu-cho, Matsue, Shimane, Japan

7 Center for Water Cycle Marine Environment and Disaster Management, Kumamoto University, 2-39-1 Kurokami, Chuo-ku Kumamoto, Japan

\section{Introduction}

In drylands such as Egypt, water scarcity hazards have increased due to small and inadequate annual rainfall of 20-200 mm at the narrow Mediterranean coast. Moreover, water availability from the Nile River is fixed and limited to 55.5 billion $\mathrm{m}^{3} /$ year. Historically, this quantity was decided in 1959 through an agreement between Sudan and Egypt to utilize Nile waters. At that time, Egypt's population was 20 million, and the available amount of water per capita was $2000 \mathrm{~m}^{3}$. The agreement has not been updated, and with a 100 million population, it has decreased to $700 \mathrm{~m}^{3}$, which is below the limit of water scarcity according to international standards. Furthermore, this value is expected to decrease to approximately $500 \mathrm{~m}^{3}$ per capita in 2025 (MWRI (Ministry of Water Resources and Irrigation) 2005). As a result, the increased diversion of water for domestic use has led to water shortages in irrigated agriculture (Ghazouani et al. 2014). 
The Egyptian government adopted new strategies through implementing water conservation projects to mitigate water wastage and maximize water use efficiency. For example, the Egypt Water Use Project was implemented to improve agricultural water management (Anderson 2008). The lesson learned from that project is to allow farmers to participate and share responsibilities in the irrigation management process. This can be achieved by (1) establishing water user associations (WUAs), (2) replacing individual pumps with collectively operated pumps, and (3) renewing the old tertiary canals (World Bank 1994). Therefore, in 1991, the Egyptian government adopted and initiated the Irrigation Improvement Project (IIP) to improve 1.5 million hectares by 2017 , of which approximately $70 \%$ is in the Nile delta. In the Nile delta, paddy cultivation has played a critical function for the environment of the Northern Nile delta, such as preventing seawater intrusion and maintaining soil quality (FAO 2002). Besides, paddy rice is the most profitable crop for farmers but also consumes more water than other crops. Considering these conditions, the MWRI has planned to grow paddy cultivation in the range of $40 \%$ to $50 \%$ of the total irrigated area (MWRI 2005).

Along with the progress of the IIP, farmers have increased paddy rice area and it has reached double the government's planned area (USDA 2006; Abou El-Hassan et al. 2015). The reasons are immaturity of the WUA and no penalty for the violation. WUA is a new concept in Egypt's irrigation system which needs more time for effective participation in terms of allocating water among themselves and adjusting their cropping pattern to handle water scarcity (Allam 2004; Rap et al. 2019). Violations by cultivating more than the planned paddy area will result in financial penalties, but the government is usually generous with this agricultural policy to gain political stability in rural areas (Kotb et al. 2000). The real challenge in the Nile Valley irrigation system is the limited opportunities to save water because the effective irrigation efficiency is already quite high at $91.3 \%$, and other attempts to save water are costly (Keller and Keller 1995). Therefore, producing more value per drop of water, cropping patterns, and shifting to higher-valued crops could play a vital role (Molden et al. 2010). Thus, how far the irrigation system at the on-farm level could bring the desired water delivery performance becomes questionable, and more investigations are required.

The assessment of water delivery performance at the tertiary canal level has been an essential point toward improving water management. The indicators proposed by Molden and Gates (1990) have been widely used for assessment of water delivery performance such as adequacy (a ratio of delivered to required water at each location and time), dependability (a temporal variation of adequacy), and equity (a spatial variation of adequacy). Evaluation of water delivery performance using these indicators in the Nile delta is extensively documented (Aly et al. 2013; EL-Agha et al. 2011; Ragab et al. 2019). However, the previous studies have been limited to the analysis of the actual paddy rice area and have not evaluated the water delivery performance under the planned paddy cultivation area. In addition, no study has shown how much water could have been saved for downstream uses. Therefore, the purpose of this study is to evaluate and compare the water delivery performance under the actual and planned conditions and to clarify the possibility of water saving.

\section{Materials and methods}

\section{Outlines of the study area}

The case study area represents the land on the North Nile delta of Egypt, which has traditionally been irrigated by surface irrigation. The main canal feeding the study area is Meet Yazid (MY), $63 \mathrm{~km}$ in length, serving approximately 82,470 ha. The MY canal is located at the end of Egypt's irrigation system that starts from Aswan High Dam. It receives a fixed amount of water based on the planned paddy rice areas (e.g., $40 \%$ to $50 \%$ of the total irrigated area).

The on-farm studies were conducted at the Dakalt branch canal, a branch canal located on the right-hand side of the MY canal, as shown in Fig. 1. The length of the Dakalt canal is $11.42 \mathrm{~km}$, and it serves approximately $2310 \mathrm{ha}$. The Dakalt canal has been improved as part of the IIP. All canals under the branch level, including the Dakalt, are operated based on a rotational system followed during summer (five days on and five days off) and winter (five days on and ten days off). The main and branch canals are operated by the irrigation department, while the tertiary canals, each serving an area of approximately $50 \mathrm{ha}$, are operated and maintained by the farmers and the WUAs. The schematic representation of the irrigation canal system and water governing entities is shown in Fig. 2.

At the initial point of each tertiary canal, a pump station was equipped with two pumps and connected with small open-lined canals to deliver water from the station to the farms. In this study, three tertiary canals were selected from the upstream (Edrega, $1.81 \mathrm{~km}$ from the starting point of the branch canal), midstream (Tayara, $4.86 \mathrm{~km}$ ), and downstream (Shams, $8.26 \mathrm{~km}$ ) along the branch canal, as shown in Fig. 1. Two pump stations were selected upstream and downstream of the tertiary canal Edrega: Edrega A (24.7 ha) and Edrega B (42.4 ha), respectively, to make a comparison among locations in both branch and tertiary canals. The chosen pump stations in the upstream and downstream of the midstream tertiary canal were Tayara A (32.2 ha) and Tayara B (39.6 ha). In the branch canal, where direct intake is allowed, Direct 3 (27.2 ha) was selected. In the downstream, 


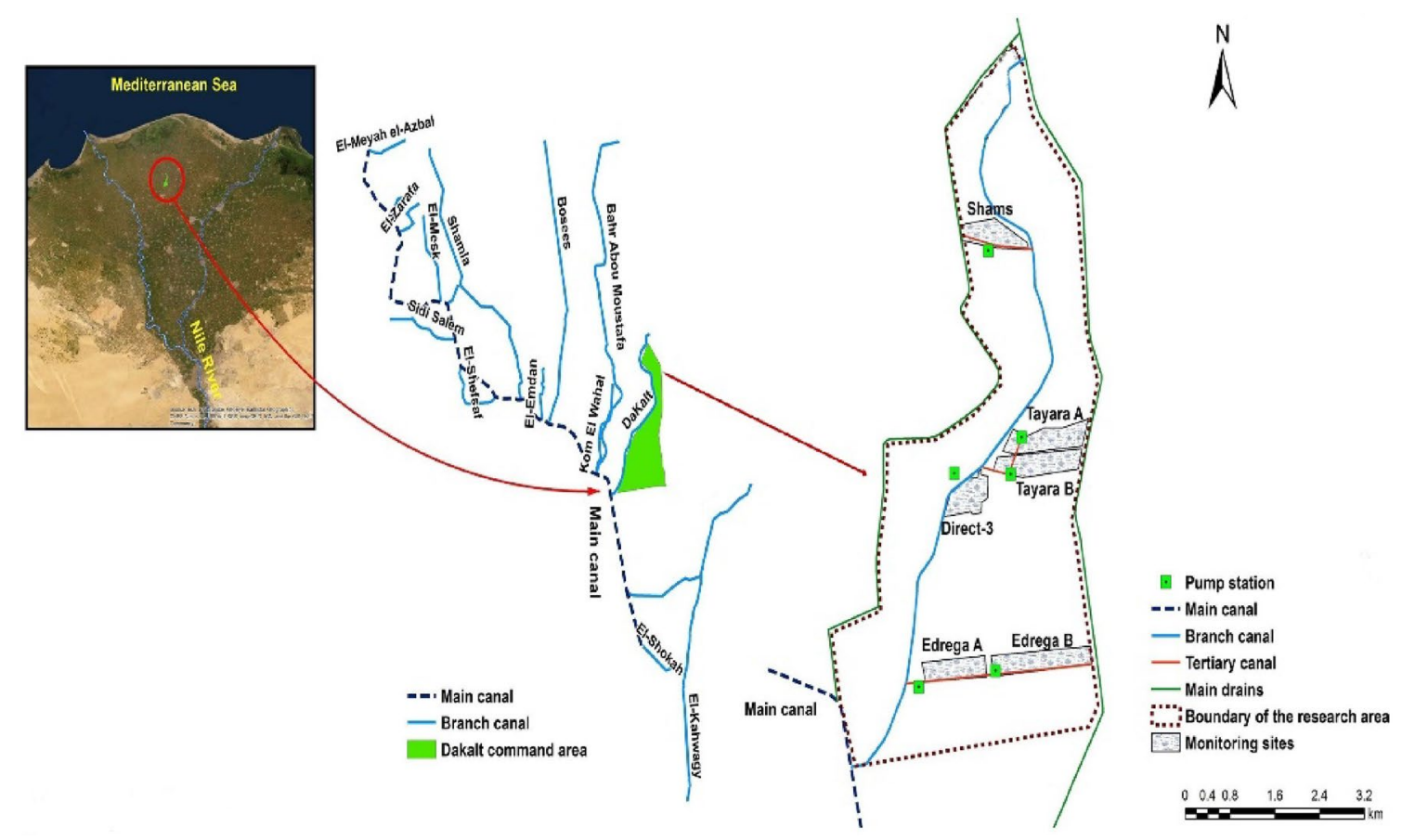

Fig. 1 Layout of the main canal irrigation networks and case study area

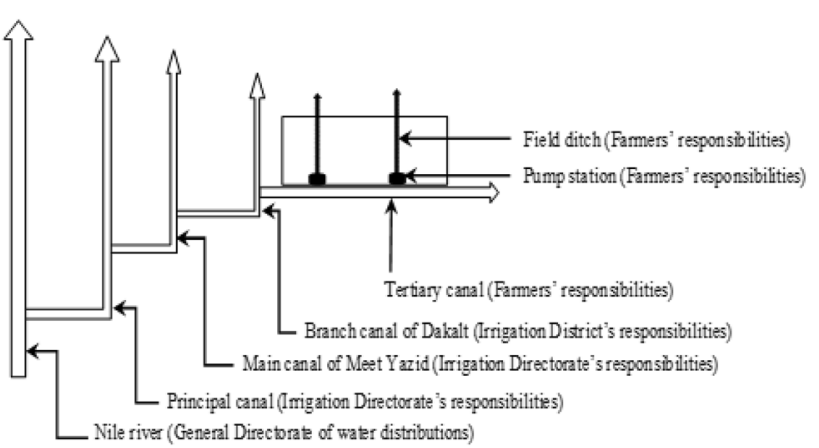

Fig. 2 Schematic representation of irrigation canal system and water governing entities

Shams (28.0 ha), located upstream of the downstream tertiary canal, was selected. Overall, five selected locations that pump water from the tertiary canals and one location that pumps water through the direct intake from the branch canal were selected.

\section{Collected data}

Egypt has two farming seasons such as winter (i.e., from October to March) and summer (i.e., from April to September). In this study, data collection and analysis were conducted in summer season because the water demand peaks and water shortage usually occur (Khater et al. 2015). The first and last months of the summer irrigation seasons (i.e.,
May and September) were not included in the analysis to prevent errors from factors such as the uncertainty of the seeding period for each crop. For the study, the branch canal water level, water supply, requirements, and crop areas were collected and calculated during the two summer seasons of 2013 and 2014.

Water requirements were calculated based on both actual cropping areas $\left(Q_{R}\right)$ and planned cropping areas $\left(Q_{R P}\right)$. $Q_{R P}$ was calculated based on the planned cropping areas (e.g., $50 \%$ paddy and $50 \%$ cotton) at all locations. These cropping areas were selected as the highest water-demanding pattern among the government's planned cropping areas. The distance between the meteorological station and the study area is about $10 \mathrm{~km}$. Water requirement was calculated based on a 10-day interval using the $\mathrm{ET}_{0}$ calculator software developed by the Land and Water Division of the Food and Agriculture Organization (Allen et al. 1998). The required meteorological daily data were collected from El Karda, Kafer El Sheikh, Egypt. Water requirement was calculated with consideration of leaching requirement (FAO 2002) and annual project efficiency of 83\% (El-Agha 2010).

Water levels were monitored by installing water level sensors (SOLINST LEVEL LOGGER) in front of the intake of each tertiary canal. The water level was recorded at 30-min intervals in June, July, and August. Water supply was estimated by multiplying the operation hours with each pump's discharge. The pump operation time was estimated based on temperature changes in the pump's pipe using thermosensors (Mole et al. 2015; Salama 2016). In this method, one sensor 
was installed on each pump's pipe and in the air. When the water flows into the pump's pipe, the temperature decreases relative to the air temperature. According to field observations when the differences in temperatures between the two sensors record less than $1.5^{\circ}$, it is considered that pump operation stopped. Based on this criterion, the temperature was recorded at a 10-min interval in June, July, and August (mid-paddy growing season). This method was employed because of the difficulty for farmers to keep accurate records of pump operation. Pump discharge was measured using a portable ultrasonic flow meter (MAXIFLO, $M U-P O-C M$ ).

The amount of water that could have been saved for downstream uses was calculated based on the differences between the actual delivered water supply $\left(\mathrm{Q}_{\mathrm{D}}\right)$ and planned water requirement $\left(\mathrm{Q}_{\mathrm{RP}}\right)$. $\mathrm{Q}_{\mathrm{D}}$ is regarded as the maximum amount of water supply because farmers cultivate higher paddy rice areas and generally pump water as much as possible during the short rotation turn.

\section{Assessing water delivery performance using $Q_{R}$ and $Q_{R P}$}

In this study, the performance indicators such as adequacy $\left(\mathrm{P}_{\mathrm{A}}\right)$, equity $\left(\mathrm{P}_{\mathrm{E}}\right)$, and dependability $\left(\mathrm{P}_{\mathrm{D}}\right)$ developed by Molden and Gates (1990) were used to assess water delivery performance. Many studies have extensively used these indicators in different countries, such as Turkey, Mali, Pakistan, and China, for the tertiary canal (Unal et al. 2004; Vandersypen et al. 2006; Shah et al. 2016; Fan et al. 2018). Water delivery performance was first assessed using the amount of water required to satisfy the government-planned cropping areas $\left(\mathrm{Q}_{\mathrm{RP}}\right)$. Then, the planned performance indicators $\left(\mathrm{P}_{\mathrm{AP}}\right.$, $\mathrm{P}_{\mathrm{EP}}$, and $\left.\mathrm{P}_{\mathrm{DP}}\right)$ were compared with the actual performance indicators $\left(\mathrm{P}_{\mathrm{A}}, \mathrm{P}_{\mathrm{E}}\right.$, and $\left.\mathrm{P}_{\mathrm{D}}\right)$ based on the actual cropping areas.

Adequacy $\left(\mathrm{P}_{\mathrm{A}}\right)$ expresses such that the irrigation system delivers the required water to irrigate crops adequately. In this study, equity $\left(\mathrm{P}_{\mathrm{E}}\right)$ and dependability $\left(\mathrm{P}_{\mathrm{D}}\right)$ express the spatial and temporal variations in $\mathrm{P}_{\mathrm{A}}$, respectively, although they are calculated initially using $Q_{D} / Q_{R}$. Because farmers are satisfied with the water delivery if the amounts of water delivered are equal or greater than their requirements. Therefore, this study evaluated dependability and equity by comparing values rather than using the evaluation criteria defined by Molden and Gates (1990), while $\mathrm{P}_{\mathrm{A}}$ is evaluated using the evaluation criteria.

The indicators were as follows:

$\mathrm{P}_{\mathrm{A}}$ and $\mathrm{P}_{\mathrm{AP}}$ are calculated using Eq. 1 .

$\mathrm{P}_{\mathrm{A}}=\mathrm{Q}_{\mathrm{D}} / \mathrm{Q}_{\mathrm{R}} ; \quad \mathrm{P}_{\mathrm{A}}=1 \quad\left(\right.$ if $\left.\mathrm{Q}_{\mathrm{D}} / \mathrm{Q}_{\mathrm{R}}>1\right)$

$\mathrm{P}_{\mathrm{AP}}=\mathrm{Q}_{\mathrm{D}} / \mathrm{Q}_{\mathrm{RP}} ; \quad \mathrm{P}_{\mathrm{AP}}=1 \quad\left(\right.$ if $\left.\mathrm{Q}_{\mathrm{D}} / \mathrm{Q}_{\mathrm{RP}}>1\right)$ where $Q_{D}$ is the amount of water delivered, $Q_{R}$ is the amount of actual water required, and $\mathrm{Q}_{\mathrm{RP}}$ is the amount of planned water required. When $\mathrm{Q}_{\mathrm{D}}$ exceeded $\mathrm{Q}_{\mathrm{R}}$ or $\mathrm{Q}_{\mathrm{RP}}$, the amount of water delivered was adequate without considering the excess amount, and the ratio of $\mathrm{Q}_{\mathrm{D}} / \mathrm{Q}_{\mathrm{R}}$ was considered to be 1.0. A value between 0.90 and 1.00 means good adequacy of water delivered. A value between 0.80 and 0.89 means fair water adequacy, while a value lower than 0.80 means poor water adequacy.

$\mathrm{P}_{\mathrm{E}}$ and $\mathrm{P}_{\mathrm{EP}}$ are calculated using Eq. 2.

$$
\begin{gathered}
\mathrm{P}_{\mathrm{E}}=1 / \mathrm{T} \sum_{\mathrm{T}} \mathrm{CV}_{\mathrm{R}}\left(\mathrm{P}_{\mathrm{A}}\right) \\
\mathrm{P}_{\mathrm{EP}}=1 / \mathrm{T} \sum_{\mathrm{T}} \mathrm{CV}_{\mathrm{R}}\left(\mathrm{P}_{\mathrm{AP}}\right)
\end{gathered}
$$

where the $\mathrm{CV}_{\mathrm{R}}$ of $\mathrm{P}_{\mathrm{A}}$ or $\mathrm{P}_{\mathrm{AP}}$ is the coefficient of the spatial variation of $\mathrm{P}_{\mathrm{A}}$ or $\mathrm{P}_{\mathrm{AP}}$ in the region $(\mathrm{R})$.

$\mathrm{P}_{\mathrm{D}}$ and $\mathrm{P}_{\mathrm{DP}}$ are calculated using Eq. 3 .

$$
\begin{gathered}
\mathrm{P}_{\mathrm{D}}=1 / \mathrm{R} \sum_{\mathrm{R}} \mathrm{CV}_{\mathrm{T}}\left(\mathrm{P}_{\mathrm{A}}\right) \\
\mathrm{P}_{\mathrm{DP}}=1 / \mathrm{R} \sum_{\mathrm{R}} \mathrm{CV}_{\mathrm{T}}\left(\mathrm{P}_{\mathrm{AP}}\right)
\end{gathered}
$$

where $\mathrm{CV}_{\mathrm{T}}$ of $\mathrm{P}_{\mathrm{A}}$ or $\mathrm{P}_{\mathrm{AP}}$ is the coefficient of the temporal variation of $\mathrm{P}_{\mathrm{A}}$ or $\mathrm{P}_{\mathrm{AP}}$ in time (T) defined by a 10-day interval during June, July, and August. The equations of equity and dependability are based on the $\mathrm{CV}$, where higher value means lower performance.

\section{Results and discussions}

\section{Cropping area}

In summer, paddy rice, cotton, and maize are grown, while wheat, clover, and sugar beet are grown in winter, as shown in Fig. 3. Based on the crop area survey described in Fig. 4, paddy rice accounted for up to $80 \%$ and $71 \%$ of the total cultivated crops in 2013 and 2014, respectively, more than the government's planned range of $40 \%$ to $50 \%$ (MWRI 2005).

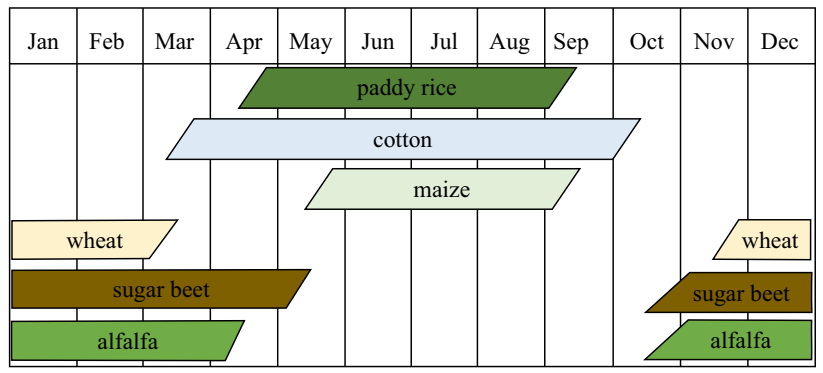

Fig. 3 Cultivated crops and their growth periods in the Nile delta 

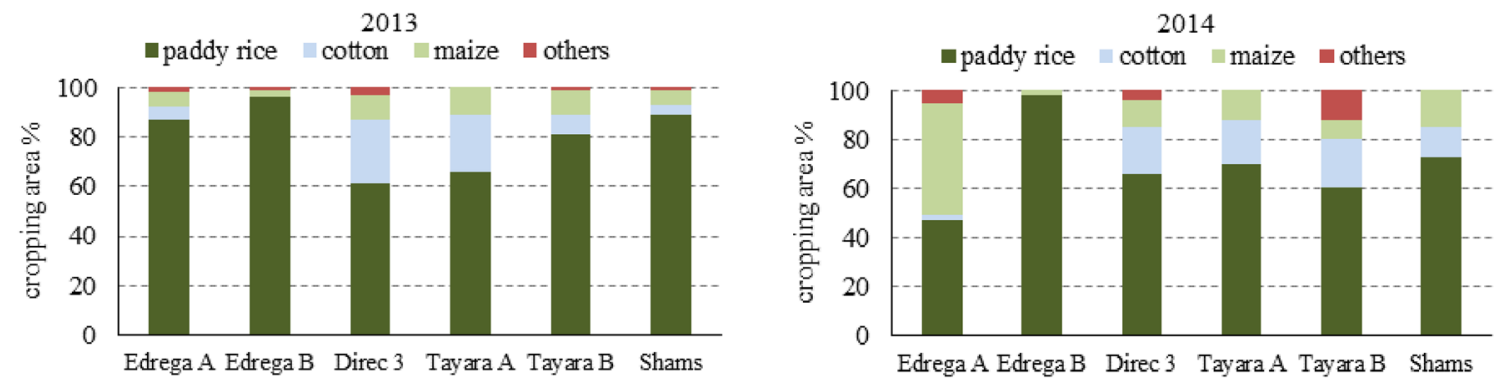

Fig. 4 Cropping area in 2013 and 2014

In the upstream location of Edrega B, paddy rice accounted for $96 \%$ and $98 \%$ of total cultivated crops in 2013 and 2014, respectively. For another upstream location, Edrega A, a drastic decrease in paddy rice areas by $46 \%$ was observed in 2014, compared to 2013 because one of the two pumps in the station required maintenance. Hence, farmers decided to reduce the paddy rice area to avoid water shortage caused by reduced water supply capacity. Paddy rice is the dominant crop, while cotton and maize accounted for $10 \%$ and $16 \%$ in $2013,12 \%$ and $16 \%$ in 2014 , respectively. Because paddy rice is the most profitable crop, farmers prefer growing paddy rice as much as possible.

\section{Branch canal water level fluctuation}

Monitoring the water level of the branch canal at different points is vital to examine whether it is high enough to pump up water from the branch canal to the tertiary canals. Figure 5 shows the water level fluctuations upstream of each tertiary canal. The stated rotation turn was scheduled as five days on and five days off, but this was not always the case midstream and downstream. Sometimes, there were only three days of water supply. In particular, the water levels in the downstream locations were frequently not enough to pump up water on the first and second days after the branch canal had been turned on.

Increased paddy rice area led the upstream farmers to pump up water as much as possible during a short time. This resulted in the drastic fluctuation of canal water level midstream and downstream and, eventually, the unreliability of water allocation. The upstream farmers' irrigation practices are not well controlled by the WUAs in the study area. The WUAs should be strengthened to mitigate this situation.

\section{Amounts of $Q_{R^{\prime}} Q_{R P}$, and $Q_{D}$}

Figure 6 shows the values of the actual water requirement $\left(Q_{R}\right)$, planned water requirement $\left(Q_{R P}\right)$, and actual water supply $\left(Q_{D}\right)$ per unit area during the water demand peaks of June, July, and August in 2013 and 2014. The $Q_{R}$ and $Q_{R P}$ were stable among locations, while $\mathrm{Q}_{\mathrm{D}}$ was not stable. The coefficient of variation $(C V)$ of $Q_{R}$ ranged from 0.03 to 0.08 , while the $C V$ of $Q_{D}$ ranged from 0.10 to 0.16 . The highest $Q_{R}$ and $Q_{R P}$ were observed in July when the highest reference evapotranspiration and crop coefficient for each crop appear. The lowest $Q_{D}$ was observed at Edrega $A$ in June 2014 due to the drastic reduction in paddy rice areas from $87 \%$ in 2013 to $47 \%$ in 2014 (Fig. 4). Shams, located at the end of the irrigation system, received the least amount of water among all locations in both years.

The stability of $\mathrm{Q}_{\mathrm{R}}$ could be related to the higher ratio of paddy rice area at all locations such as 78\% in 2013 and $70 \%$ in 2014 . $\mathrm{Q}_{\mathrm{RP}}$ was completely the same among locations because the same cropping pattern such as $50 \%$ cotton and $50 \%$ paddy rice is employed to calculate $\mathrm{Q}_{\mathrm{RP}}$. The possible reason for the instability of $Q_{D}$ is the difficulty to pump water properly due to the irregularity of the branch canal's water level (Fig. 5).

\section{Water delivery performance}

\section{Adequacy $\left(\mathrm{P}_{\mathrm{A}}\right.$ and $\left.\mathrm{P}_{\mathrm{AP}}\right)$}

The $\mathrm{P}_{\mathrm{A}}$ and $\mathrm{P}_{\mathrm{AP}}$ of each location in 2013 and 2014 are shown in Fig. 7. Overall, the $\mathrm{P}_{\mathrm{A}}$ of some locations such as Edrega A, Direct 3, and Tayara B was evaluated as good or fair in both years. As to Edrega $\mathrm{B}, \mathrm{P}_{\mathrm{A}}$ was poor in 2013 but fair in 2014, while the $\mathrm{P}_{\mathrm{A}}$ of Tayara $\mathrm{A}$ was fair in 2013 but poor in 2014. As to Shams, $P_{A P}$ was fair, while $P_{A}$ was poor in both years. $\mathrm{P}_{\mathrm{AP}}$ was good or fair in each month, except in late July at all locations.

The lower $\mathrm{P}_{\mathrm{A}}$ of some locations was caused by the overplanting paddy rice area and incoordination of water distribution among WUAs. As the ratio of the paddy rice areas was higher than planned, the $Q_{R}$ was more increased than $\mathrm{Q}_{\mathrm{RP}}$. This induced farmers, especially upstream, to pump more water than planned during the intake period due to incoordination among WUAs. As a result, the water level downstream lowered to the level that farmers were unable to pump during the first and second days of the intake period (Fig. 5). Especially, in late July, $\mathrm{P}_{\mathrm{A}}$ and $\mathrm{P}_{\mathrm{AP}}$ were lower at 

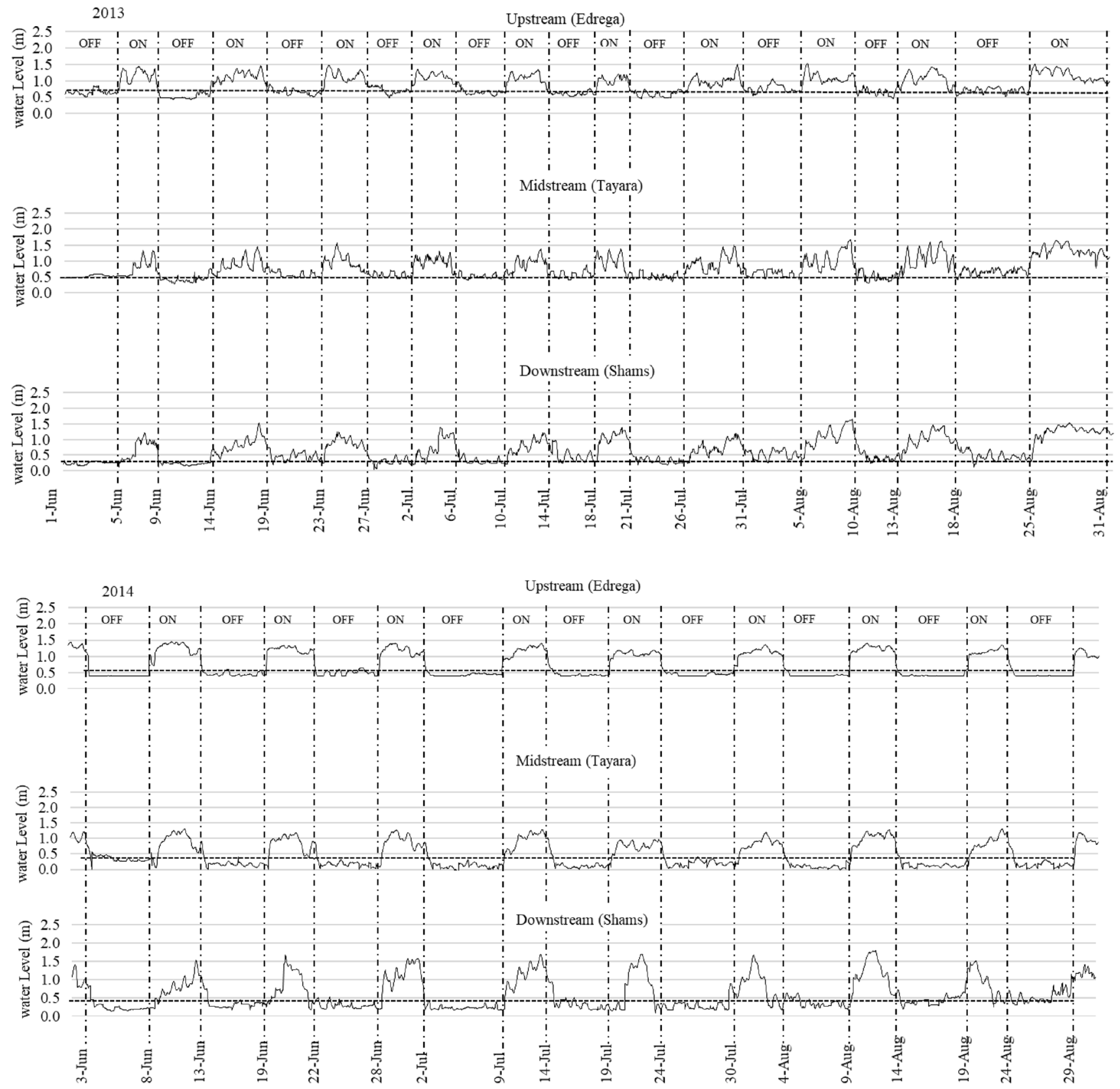

Fig. 5 Branch canal water level in 2013 and 2014 (Horizontal dashed lines show the minimum water levels for pumping water)

most locations in both years due to higher $\mathrm{Q}_{\mathrm{R}}$ and $\mathrm{Q}_{\mathrm{RP}}$. The increased inability to pump up sufficient water caused unreliability of water distribution services and created a vicious cycle of trying to pump as much water as possible.

\section{Equity $\left(P_{E}\right.$ and $\left.P_{E P}\right)$ and dependability $\left(P_{D}\right.$ and $\left.P_{D P}\right)$}

Spatial values of equity $\left(\mathrm{P}_{\mathrm{E}}\right)$ and planned equity $\left(\mathrm{P}_{\mathrm{EP}}\right)$ in both years are shown in Fig. 8. The temporal values of dependability $\left(\mathrm{P}_{\mathrm{D}}\right)$ and planned dependability $\left(\mathrm{P}_{\mathrm{DP}}\right)$ for selected locations are shown in Fig. 9. By comparing $\mathrm{P}_{\mathrm{E}}$ and $\mathrm{P}_{\mathrm{EP}}$, the equity improved in each period except late July 2013 if the ratio of the paddy rice was controlled. Overall, equity improved from 0.22 to 0.10 in 2013 and from 0.18 to 0.06 in 2014. The $P_{D P}$ improved at all locations. In 2013, the overall $\mathrm{P}_{\mathrm{DP}}$ improved from 0.29 to 0.11 , and from 0.21 to 0.07 in 2014. Especially downstream, the $\mathrm{P}_{\mathrm{D}}$ improved from 0.43 to $0.20\left(\mathrm{P}_{\mathrm{DP}}\right)$ in 2013 and from 0.20 to $0.15\left(\mathrm{P}_{\mathrm{DP}}\right)$ in 2014; however, it was worse compared to the other locations.

Equity becomes lower if the $\mathrm{P}_{\mathrm{A}}$ values differ as it expresses the $\mathrm{CV}$ of $\mathrm{P}_{\mathrm{A}}$ among locations. Due to the incoordination of water allocation, $\mathrm{P}_{\mathrm{A}}$ was higher at some locations 

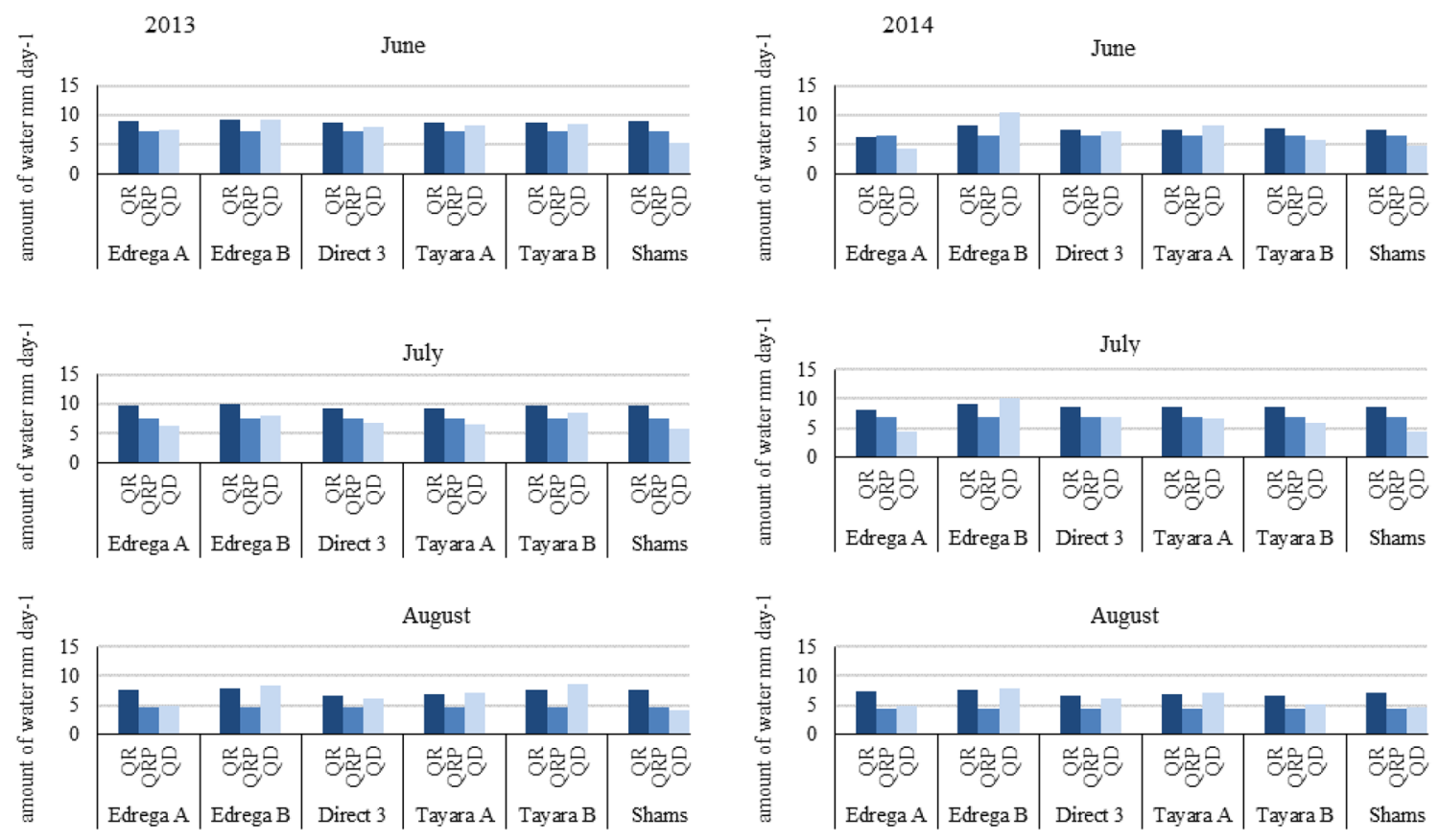

Fig.6 Actual water requirement $\left(Q_{R}\right)$, planned water requirement $\left(Q_{R P}\right)$, and the actual amount of water delivered $\left(Q_{D}\right)\left(m^{2}\right.$ day $\left.{ }^{-1}\right)$ for selected locations in 2013 and 2014

where more water was pumped and $\mathrm{P}_{\mathrm{A}}$ was lower at the other locations where less water was pumped. Therefore, equity will be further reduced under water scarcity conditions. Further, even if farmers followed the planned ratio of paddy rice area, the equity in late July 2013 was low (0.22) compared to other periods. This could be due to insufficient water supply to the Dakalt branch canal and excessive water withdrawal at the tertiary canals upstream of the study locations.

Dependability becomes lower if the $\mathrm{P}_{\mathrm{A}}$ values differ as it expresses the $\mathrm{CV}$ of $\mathrm{P}_{\mathrm{A}}$ in time. Dependability improved at most locations under the planned paddy rice area because $\mathrm{P}_{\mathrm{AP}}$ became 1 for some periods due to lower $\mathrm{Q}_{\mathrm{RP}}$ (Fig. 7). The dependability of Shams was worse because $\mathrm{P}_{\mathrm{A}}$ was low in not only late July but also other periods, such as early June and early August. The control of the paddy rice area improved equity and dependability. The coordination of water distribution among WUAs is inevitable for further improvement.

\section{Potential water saving}

This study quantified the potential water saving through changes in the paddy rice area from current overplanting to the government's planned area. Overall, with the planned cropping areas, $\mathrm{Q}_{\mathrm{RP}}$ decreased from $1.51 \mathrm{Mm}^{3}\left(\mathrm{Q}_{\mathrm{R}}\right)$ to $1.14 \mathrm{Mm}^{3}$ during the examined periods in 2013 and from $1.29 \mathrm{Mm}^{3}\left(\mathrm{Q}_{\mathrm{R}}\right)$ to $1.00 \mathrm{Mm}^{3}$ in 2014 . Under the condition that paddy rice area is the upper limit planned by the government, $23.8 \%$ of $\mathrm{Q}_{\mathrm{R}}$ could be potentially decreased in both years. In 2013, the total amount of water saved from upstream and midstream was $14.8 \%$, while downstream, no water was saved $(-6.2 \%)$. The same trend was observed in 2014, when the total amount of water saved from upstream and midstream was $15.6 \%$, while downstream lacks water by $6.1 \%$. Overall, the total amounts of water that could have been saved for downstream uses from the six assessed locations were $12.3 \%$ in 2013 and $9.6 \%$ in 2014.

Furthermore, there are 40 tertiary canals with 72 pump stations in the branch canal and 13 tertiary canals upstream of Edrega. The overall water shortage in the irrigated areas of the branch canal was considered to be caused by excess water withdrawal from these tertiary canals, as the ratio of paddy rice area in these irrigated areas was higher than the government's upper limit. There is a need to control the paddy rice area to reduce the water demand peak. Thus, controlling the paddy rice area at the recommended level would save water and improve the water delivery performance along the branch canal between upstream, midstream, and downstream. To achieve these, the WUAs are required to set and follow rules for control of overplanting paddy rice and coordination of water allocation.

\section{Conclusions}

The impact of overplanting paddy rice on irrigation water delivery performance was assessed by comparison of actual paddy rice planting and the government's planned 

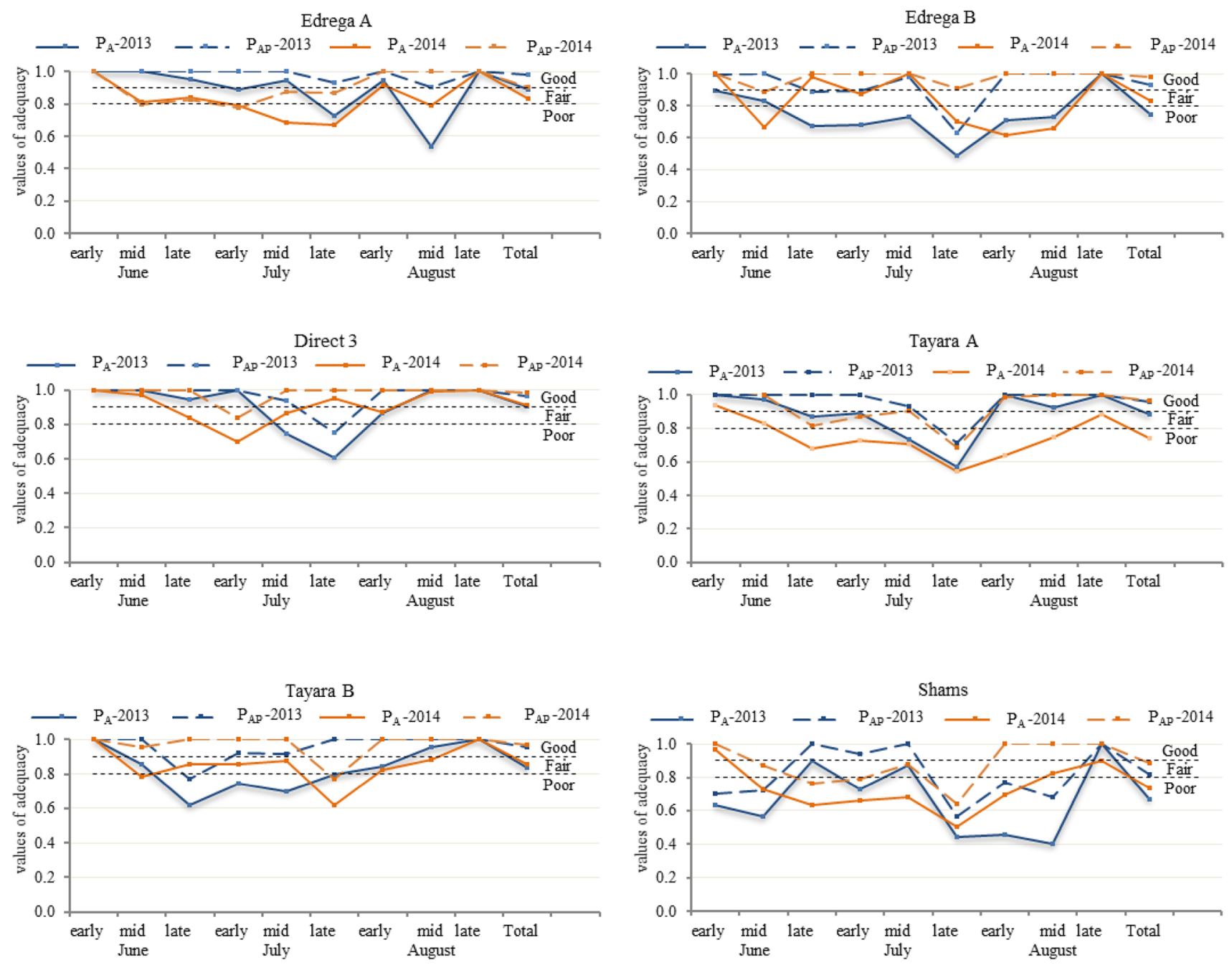

Fig. 7 Actual adequacy $\left(\mathrm{P}_{\mathrm{A}}\right)$ and planned adequacy $\left(\mathrm{P}_{\mathrm{AP}}\right)$ for selected six locations in 2013 and 2014

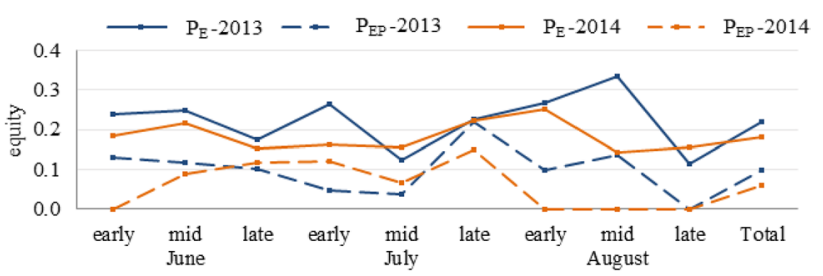

Fig. 8 Actual equity $\left(\mathrm{P}_{\mathrm{E}}\right)$ and planned equity $\left(\mathrm{P}_{\mathrm{EP}}\right)$ in 2013 and 2014

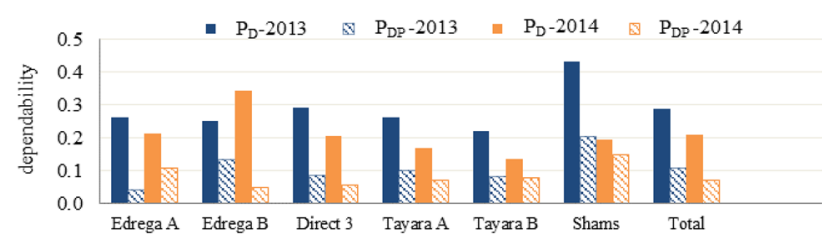

Fig. 9 Actual dependability $\left(\mathrm{P}_{\mathrm{D}}\right)$ and planned dependability $\left(\mathrm{P}_{\mathrm{DP}}\right)$ for selected locations in 2013 and 2014
( $40 \%$ to $50 \%$ of the total irrigated area) conditions at the six selected locations in the Dakalt branch canal of the Nile delta, Egypt. Adequacy (a ratio of water supply to the water demand), dependability (a temporal variation of adequacy), and equity (a spatial variation of adequacy) were employed as performance indicators. In addition, potential water saving was quantified by comparison of the current water supply under overplanting paddy rice and the water demand under the planned paddy rice area. The results show that under the condition of the planned paddy rice area, the adequacy, equity, and dependability improved more than those of the actual. However, adequacy under the planned condition was lower at most locations due to higher water demand. The amounts of water that could have been saved for downstream uses from the six selected locations ranged between 10 and $12 \%$ of the current water supply. The increase in the conditions of not withdrawing sufficient water reduced the reliability of 
water distribution services which fell into a vicious cycle of trying to withdraw as much water as possible. The coordination of water distribution among WUAs is inevitable for further improvement of water delivery performance and water saving. The WUAs are required to set and follow rules for control of overplanting paddy rice and coordination of water allocation.

In order to improve water delivery performance and save water, the next step is to analyze the current performance assessment combined with questionnaires and interviews with farmers and WUAs on their irrigation water management decisions.

Funding This study was conducted under the "Development of crop husbandry technology in marginal rain fed environment using dryland plant resources" Project by Tottori University and was partially supported by International Platform for Dryland Research and Education, Tottori University (JP) and The National Water Research Center (NWRC).

\section{Declarations}

Conflict of interest The authors declare that they have no conflict of interest.

Open Access This article is licensed under a Creative Commons Attribution 4.0 International License, which permits use, sharing, adaptation, distribution and reproduction in any medium or format, as long as you give appropriate credit to the original author(s) and the source, provide a link to the Creative Commons licence, and indicate if changes were made. The images or other third party material in this article are included in the article's Creative Commons licence, unless indicated otherwise in a credit line to the material. If material is not included in the article's Creative Commons licence and your intended use is not permitted by statutory regulation or exceeds the permitted use, you will need to obtain permission directly from the copyright holder. To view a copy of this licence, visit http://creativecommons.org/licenses/by/4.0/.

\section{References}

Abou El-Hassan WH, El-Kassar G, Fujimaki H, Kitamura Y, Khater A (2015) Assessment of cost-effective alternatives for improving irrigation systems in the Nile Delta. Irrig Drain Syst 454:463-464. https://doi.org/10.1002/ird.1931

Allam MN (2004) Participatory irrigation water management in Egypt: review and analysis. In: Hamdy A, Tüzün M, Lamaddalena N, Tod orovic M, Bogliotti C (eds) Participatory water saving management and water cultural heritage. CIHEAM, Bari, pp 123-131. http://ressources.ciheam.org/om

Allen RG, Pereira LS, Raes D, Smith M (1998) Crop evapotranspiration: Guidelines for computing crop water requirements. FAO Irrigation and drainage paper 56. Food and Agriculture Organization, Rome. http://www.fao.org/docrep/x0490e/x0490e00.htm

Aly AM, Kitamura Y, Shimizu K (2013) Assessment of irrigation practices at the tertiary canal level in an improved system-a case study of Wasat area, the Nile Delta. Paddy Water Environ 445:454-511. https://doi.org/10.1007/s10333-012-0335-1

Anderson IAM (2008) Efficient water use for agricultural production (EWUAP) project: agricultural water in the Nile Basin- an overview. Bethersden, Kent, England. http://nileis.nilebasin.org/ system/files/over_0.pdf. Accessed Apr 2008

El-Agha DE (2010) Performance assessment of the irrigation water management in old lands of the Nile Delta. Dissertation, University of Cairo, Egypt

El-Agha DE, Molden DJ, Ghanem AM (2011) Performance assessment of irrigation water management in old lands of the Nile delta of Egypt. Irri Drain Syst 215:236-325. https://doi.org/10. 1007/s10795-011-9116-Z

Fan Y, Gao Z, Wang S, Chen H, Liu J (2018) Evaluation of the water allocation and delivery performance of Jiamakou irrigation scheme, Shanxi. China Water. https://doi.org/10.3390/w10050654

FAO (Food and Agricultural Organization) (2002) Agricultural drainage water management in arid and semi-arid areas. FAO Irrigation and Drainage Paper No. 61; FAO: Rome, Italy

FAO (Food and Agriculture Organization) (2002) Rice information. http://www.fao.org/3/y4347e/y4347e00.htm. Accessed Dec 2002

Ghazouani W, Molle F, Swelam A, Rap E, Abdo A (2014) Understanding farmers' adaptation to water scarcity: a case study from the western Nile Delta, Egypt. International Water Management Institute (IWMI). Research Report 160; IWMI: Colombo, Sri Lanka. https://doi.org/10.5337/2015.200

Keller AA, Keller J (1995) Effective efficiency: a water use efficiency concept for allocating freshwater resources, Center for Economic Policy Studies. Discussion Paper No. 22: Winrock International, USA. https://econpapers.repec.org/RePEc:iwt:worppr:h044344

Khater A, Kitamura Y, Shimizu K, Abou El Hassan W, Fujimaki H (2015) Quantitative analysis of reusing agricultural water to compensate for water supply deficiencies in the Nile Delta irrigation network. Paddy Water Environ 13:367-378. https://doi.org/10. 1007/s10333-014-0454-y

Kotb THS, Watanabe T, Ogino Y, Tanji KK (2000) Soil salinization in the Nile Delta and related policy issues in Egypt. Agric Water Manag 239:261-343. https://doi.org/10.1016/S0378-3774(99) 00052-9

Molden DJ, Gates TK (1990) Performance measures for evaluation of irrigation-water-delivery systems. J Irrig Drain Eng 804:823-116. https://doi.org/10.1061/(ASCE)0733-9437(1990)

Molden D, Oweis T, Steduto P, Bindraban P, Hanjra MA, Kijne J (2010) Improving agricultural water productivity: between optimism and caution. Agric Water Manag 528-535-97. https://doi. org/10.1016/j.agwat.2009.03.023

Mole F, Abou El Hassan W, Salama S, Al-Agha DE, Rap E (2015) Water and salt dynamics at the Meso-level in IIIMP Areas, Mares El Gamal canal. Water and salt management in the Nile Delta. International Water Management Institute (IWMI). Project Report No. 5. IWMI, WMRI: Cairo, p 11 https://doi.org/10.13140/RG.2. 2.35323.62246

MWRI (Ministry of Water Resources and Irrigation) (2005) Water for the future: National Water Resources plan 2017. Planning Sector, Cairo. http://extwprlegs1.fao.org/docs/pdf/egy147082.pdf. Accessed Jan 2005

Ragab MFS, Shimizu K, Abou El Hassan W, Nakamura K, Watanabe T (2019) Investigation of irrigation performance at the tertiary canal level in the Nile Delta of Egypt. Paddy Water Environ 69:74-17. https://doi.org/10.1007/s10333-019-00698-2

Rap E, Molle F, Al-Agha DE, Abou El Hassan W (2019) The limits to participation: branch-canal water user associations in the Egyptian Delta. Water Int 31:50-44. https://doi.org/10.1080/02508060. 2018.1554766

Salama SS (2016) Integrated assessment of on-farm water management under improved irrigation system in the Nile Delta of Egypt. Dissertation, University of Ain Shams, Egypt

Shah M, Anwar A, Bell A, Ul-haq Z (2016) Equity in a tertiary canal of the Indus basin irrigation system (IBIS). Agric Water Manag 178:201-214. https://doi.org/10.1016/j.agwat.2016.09.018 
Unal HB, Asik S, Avci M, Yasar S, Akkuzu E (2004) Performance of water delivery system at tertiary canal level: a case study of the Menemen Left Bank irrigation system, Gediz Basin. Turkey Agric Water Manag 155:171-265. https://doi.org/10.1016/j.agwat. 2003.10.002

USDA (United States Department of Agriculture) (2006) World Food Statistics and Graphics. http://worldfood.apionet.or.jp/graph/ index-e.html
Vandersypen K, Bengaly K, Keita ACT, Sidibe S, Raes D, Jamin JY (2006) Irrigation performance at tertiary level in the rice schemes of the office Du Niger (Mali): adequate water delivery through over-supply. Agric Water Manag 144:152-183. https://doi.org/10. 1016/j.agwat.2005.11.003

World Bank (1994) Irrigation improvement project. Washington. http:// documents.worldbank.org/curated/en/518461468021582182/ Egypt-Irrigation-Improvement-Project 